\title{
The Linkage of El Niño-Induced Peat Fires and Its Relation to Current Haze Condition in Central Kalimantan
}

\author{
NINA YULIANTI ${ }^{1,2,3}$, KITSO KUSIN ${ }^{2,3}$, DAISUKE NAITO ${ }^{4,5,6}$, MASAHIRO \\ KAWASAKI $^{5}$ OSAMU KOZAN $^{5}$, AND KURNIAWAN EKO SUSETYO ${ }^{6}$ \\ ${ }^{1}$ Faculty of Agriculture, University of Palangka Raya, Palangka Raya, Indonesia \\ ${ }^{2}$ Graduate Program of Environmental Science, University of Palangka Raya, Palangka Raya, Indonesia \\ ${ }^{3}$ UPT. LLG - CIMTROP, University of Palangka Raya, Palangka Raya, Indonesia \\ ${ }^{4}$ Faculty of Agriculture, Kyoto University, Kyoto, Japan \\ ${ }^{5}$ CSEAS, Kyoto University, Kyoto, Japan \\ ${ }^{6} \mathrm{CIFOR}$, Bogor, Indonesia
}

\begin{abstract}
Annual forest and peatland fires in Central Kalimantan are reaching more than thirty percent of total fires in Kalimantan Island. Symptoms of climate change in the form of increasingly an extreme weather and global climate phenomena support the severity of fires occurrences and transboundary haze. This study aims to investigate the latest severe fire and haze condition in Central Kalimantan. Hotspot data was from 2006 to 2019. Visibility, Particle Matter Size 10 (PM 10) and Air Pollution Standard Index (PSI) data was from El Niño in 2014/2015 comparison to La Niña in 2016/2017. The results showed that the top incidents in peatland occurred not only very strong in 2015 but also weak El Niño in 2006. The most of dense hotspots density in the last fourteen years (> 50\% of fires in the area) found in Pulang Pisau, Palangka Raya and Kapuas. The haze condition in Palangka Raya was getting thicker at the end of October. The dangerous of PSIs with PM10 concentrations of more than $500 \mu \mathrm{g} \mathrm{m}^{-3}$ occurred for 2 (two) months, from the end of August to the early of November 2015. PSIs in highest fire occurrences in 2015 is about 50 times greater than the lowest fire occurrences in 2017. Low visibility in 2015 was ranging from 200 to $900 \mathrm{~m}$ during the peak air pollution season. Thus, this El Niño-induced fires and haze in peatland area could threaten thousand peoples and cause harmful feed-back to the environment.
\end{abstract}

Key words: El Niño; fires; haze; peatland

\section{INTRODUCTION}

Central Kalimantan has the largest areas of tropical peatland in Indonesia covering an area of about 2 million ha (Wetland, 2004). Over millions of years, this area has accumulated organic carbon and acted as a carbon sink. Correspondence: Nina Yulianti. Faculty of Agriculture, University of Palangka Raya, Palangka Raya, Indonesia, Email: nyulianti@agr.upr.ac.id

Journal of Wetlands Environmental Management Vol 8, No 2 (2020) 100 - 116 http://dx.doi.org/10.20527/jwem.v8i2.221
However, in 1996/1997, more than one million ha of peat swamp forest (hereafter PSF) of Central Kalimantan has drained by drainage channels for conversion to agricultural land under the Mega Rice Project (hereafter MRP). The effect was a lowering of ground water levels (hereafter GWL), mainly in the following dry season, that are a cause of severe forest and land fires. Page et al. (2002) showed that as much as $70 \%$ of the PSF was 
destroyed by the fire in $1997 / 1998$. Further, there is evidence that a slice of forests near the Sebangau National Park in the part of the MRP disappeared in connection with the dense hotspots in 2006. The highest numbers of fire occurrence prior to 2018 in this province have been recorded in the years of El Niño (Putra \& Hayasaka, 2011; Yulianti \& Hayasaka, 2013; Hayasaka \& Sepriando, 2018).

The population in Central Kalimantan is $2,212,089$ peoples with the density of only 15 people $/ \mathrm{km}^{2}$ based on the 2010 population census. More than half the province is still covered by forests which, however, are shrinking rapidly as the logging industry expands in last decade. The MRP area is one of the well-known examples of vast development areas for paddy field in the world. The failure project was initiated in large area of peatland in the south-eastern part of the province in middle 1990s. The area of MRP that is now not under cultivation (EMRP) may be subject to uncontrolled and unpredictable fires. Peat soil, which characterizes within the areas, is highly flammable (Yulianti et al. 2014), causing widespread fires and making fires difficult to extinguished especially in the dry condition. With repeated fires, deforestation and loss of forest cover are unavoidable in near future. Several studies have been proved that almost $90 \%$ of all modern forest and land fires around the world have been recorded as being caused by humans [Putra et al. 2008; Barbara et al. 2015; Yulianti, 2018). Careless actions such as leaving a campfire and throwing cigarette butts could resulting in a disaster. Deliberate actions such as burning debris, garbage and fireworks are also other substantial causes of fire. Land clearing activities using the slash-burn method are also very easy to cause widespread fires and even spread to the adjacent forest areas. Some people may also intentionally burn to destroy land cover, houses or other property. As a result, neighbouring land can be affected badly, which this often occurs near the settlement.

The great influence of humans on the environment of fire has been notified by several previous researchers (Conedera \& Tinner, 2000; Caldararo, 2012; Taylor, 2010; Scott et al, 2014; MacDonald, 2017). Human needs for fire are increasing along the history, known as one part of the culture of farming not only in most of Asian countries but also in the aboriginal communities in America and Europe. Under conditions of climate change that are increasingly evident, the frequency of forest and land fires caused by human activities has brought a disaster, such as that experienced by the Indonesian region, especially in Central Kalimantan (Syphard et al. 2018; Struzik, 2017; Harvey, 2016; Hayasaka et al. 2014; Yulianti et al. 2012). However, public awareness and recognition, as well as decision-makers against catastrophic fires and haze transboundary, seem not good enough in recent year. It is manifested by the widespread use of the slash-burn for land clearing. On the other side, the law enforcement against the actual mastermind of the burning arson is still mistargeted. The advanced prevention and mitigation are not established yet by the authorities. This results the vulnerability of millions of people within and out of the province boundaries exposed to the bad impact of fires and poor air quality when thick haze occurs for months.

The concentration of particulate matter (PM10) in Palangka Raya (Central Kalimantan) in 2019 showed concentrations $>2000 \mu \mathrm{g} \mathrm{m}^{-3}$ (Hayasaka \& Sepriando, 2018), which was far higher than in 2002 and 2006, about $2000 \mu \mathrm{g} \mathrm{m}^{-3}$ (Hayasaka et al. 2014). Since the safe limit for human health PM10 is $<400 \mu \mathrm{g} \mathrm{m}^{-3}$ according to the technical 
guidelines for the calculation and reporting air pollution standard index of Indonesia, the air quality in Palangka Raya was very unhealthy conditions and increase the sensitivity of patients with asthma and bronchitis.

These fires also produce toxic smoke as well as they release large amounts of greenhouse gases (GHG) (Stockwell et al. 2016). Huijnen et al (2016) estimated that forest and land fires in Central Kalimantan in 2015 released about 11 million tons of carbon per day, exceeding the daily level of 8.9 million tons of carbon emissions from the entire European Union. $\mathrm{CO}_{2}$ emission from severe occurrence such in 1997 was an possible average maximum $4.32 \mathrm{Gt}^{-1}$ in (Hooijer et al. 2006). Thus, Indonesia has been positioned as one of the carbon emitting countries and the famous exporter of hazerelated-pollution among countries in Southeast Asia (Heil et al. 2006; Kim et al. 2016; Van Mead, 2017). Prior to 2019, the combination of forest destruction, unwise land clearing and severe El Niño climate events has caused the Central Kalimantan as disaster prone areas, mainly severe forest and peatland fires and transboundary haze (Yulianti, 2018). Therefore, we would like to investigate the linkage of climate (El Niño), peat fire and severe haze condition in Central Kalimantan as the tool of the preparedness of 2020 El Niño event.

\section{MATERIAL AND METHODS}

\section{Study Target}

The study site was located in the Central Kalimantan (CK), Indonesia, ranging from $1^{\circ} 30^{\prime}$ to $4^{\circ} 45^{\prime} \mathrm{S}$ and from $110^{\circ} 30^{\prime}$ to $115^{\circ} 15 \mathrm{E}$ (Fig. 1). This province is comprised of one city and thirteen regencies, which covers a average of $1.42 \mathrm{Gt} \mathrm{y}^{-1}$ as a lower limit with the

total land area of about 153,000 $\mathrm{km}^{2}$ (approximately $28.8 \%$ of the size of Indonesian Borneo). The total peatland area of $\mathrm{CK}$ is about 26,444 $\mathrm{km}^{2}$, which is approximately $400 \%$ larger than that of Jakarta Province at $662 \mathrm{~km}^{2}$. The distribution of peatland is shown in a line color (blue) in Figure 2. The main area of peatland has developed in a large area of lowland on the southern coast, covering a deepest peat or dome (over ten meter) in former MRP area ( $\sim 56.7 \%$ of the total CK's peatland) and Sabangau National Park ( $20.5 \%$ of the CK's peatland). Accumulation of tropical peatlands in $\mathrm{CK}$ are formed in wet areas with poor aeration, such as in shallow lakes, ponds, swamps and alluvial areas, as the result of natural eutrophication for the time of thousand years (Noor, 2001). These areas are much affected by the conditions of rainwater and prominent rivers (dotted blue color in Figure 2) such as Palangka Raya, Pulang Pisau, Kapuas, Katingan and South.

The peatland in Central Kalimantan was decided as the initial target of Peatland Restoration Agency (known as BRG) since 2016 until 2020. BRG and KLHK introduced the terminology of peat hydrological units (PHU) to represent a land that is formed between two rivers, including organic soil (peat) or not. The soil type of PHU is not only peat but also mineral soil associated with peat. Central Kalimantan is divided by 37 PHUs, two PHUs are across the Central - South Kalimantan Province and two PHUs are across the Central - West Kalimantan Province. The former MRP area has six PHUs, namely PHU Kahayan - Kapuas (diagonal blue color), PHU Kahayan - Sebangau (diagonal orange color), PHU Kapuas -Barito (diagonal red color), PHU Kapuas - Mangkutup (diagonal purple color), PHU Kapuas - Murui (diagonal green color) and PHU Katingan - Sebangau 
(diagonal black color),as shown in Figure 2 . The PHUs are located across regencies such as Palangka Raya, Pulang Pisau, Kapuas, Katingan and South Barito.

The Indonesian Ministry of Forestry and Environment (known as KLHK) has determined three main functions of forests in peatland and peaty mineral areas within PHU, so called nature reserve (purple), conservation forest (bright green), and conservation area (blue with black border) as shown by Figure 2 . Meanwhile the area that referred to other land uses (white) and forest production (yellow) commons overlapping with the concessions of oil palm, mining and forest plantations, particularly in the western. Most of peatland area (approximately 50\%) is categorized as production forest and production forest with limited uses. It is means the forest areas can be lent for concessions to be managed and used for the other uses. Only four spots are categorized as areas that are still preserved as natural forest (purple), namely Sebangau National Park, Tanjung Puting National Park, Swamp Forests in Kapuas and East Barito.

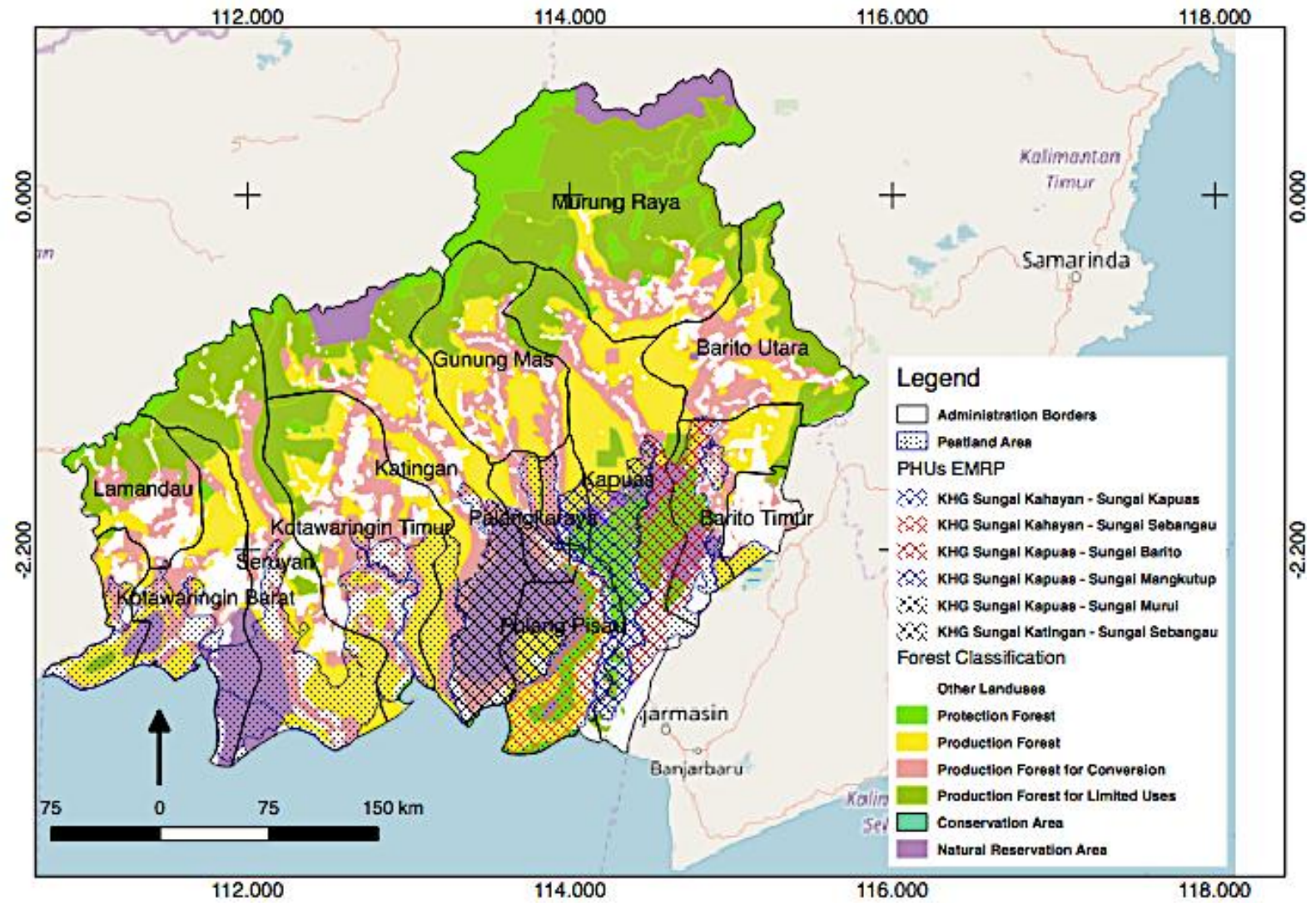

Figure 1. Study area, the peat hydrological unit and the land covers

\section{Hotspot Analysis}

First stage was the selection of the hotspot data only for Central Kalimantan areas. MODIS hotspot data (Collection 6 active fire product) from 2006 to 2019 were used in this study. Recently, MODIS data has been Journal of Wetlands Environmental Management extracted automatically through the FIRMS website (Fire Information for Resources Management

System, https://earthdata.nasa.gov/ data/near-real-timedata/firms). The total amount of 14-year hotspot data for Kalimantan, reached 343, 947 hotspots. However, this study target is only 
selected confidence of hotspot greater than or equal to $60 \%$ for Central Kalimantan, which is represent an average of $30 \%$ of the total in Kalimantan.

Secondly, this study was developed a dynamic heatmap analysis to easily find out a high concentration area from hotspot data. This can be a representation of data that uses a system of color-coding to represent different values. We interpolate the value from known points value, so called Kernel Density Estimation (KDE). KDE performs calculation by considering arbitrary search radius and the cell size. The values were categorized the map with five colour as follows as: dark blue (1 50.7), light blue (50.8 - 99.9), yellow (100 149.9), orange (150 -199.9) and red (> 200).

Thirdly, box plots (also known as box and whisker plots) use to define whether the fires occur on peatlands or not. This is a type of chart in explanatory data analysis to visually and show the distribution of numerical data and skewness through displaying the data quartiles (or percentiles) and averages. A boxplot is a standardized way of displaying the distribution of data based on a five number summary ("minimum", first quartile (Q1), median, third quartile (Q3), and "maximum"). The dataset at this stage is the percentage value of hotspots 2006 to 2019 on peatlands in each of the selected regencies.

Lastly, supporting spatial data in this study were obtained from Peatland Restoration Agency (for 2016 data), Ministry of Environmental and Forestry (for 2012 data), BAKORSURTANAL (for 2012 data), Wetland (for 2004 data) and www.kebakaranhutan.or.id (for 2018 data). Layers were produced using Quantum GIS and Cartographica softwares for analysis. The output are fire prone and fire risk maps on an annual basis. Scoring of fire risk based on biophysical and hotspot history consist five levels of severity namely " 5 " very high, " 4 " high, "3" moderate, " 2 " low, " 1 " very low.

\section{Definition of Oceanic Nino Index (ONI)}

The NOAA (National Oceanic and Atmospheric Administration) definition of $\mathrm{El}$ Niño events and their SST (Sea Surface Temperature) anomaly values were also used to analyze their relationship with fire activities as in Table 1. The El Niño events began with an abnormally rising water temperature in the central and eastern equatorial Pacific Ocean. It is causing the east trade winds moving from East to West to weaken. The evaporation of sea water causes the formation of clouds. The air pressure in the western Pacific Ocean has increased and the growth of clouds in the eastern seas of Indonesia is hampered. El Niño events cause a decrease in rainfall in some parts of Indonesia such Central Kalimantan areas. The Oceanic Niño Index (ONI) is 3 month running mean of Extended Reconstructed Sea Surface Temperature Version 4 (ERSST.v4) anomalies in the Niño 3.4 region within an area of $5^{\circ} \mathrm{N}-5^{\circ} \mathrm{S}$ and $120^{\circ}$ $170^{\circ} \mathrm{W}$ (Huang et al. 2017). The values at or above the $+0.5^{\circ}$ anomaly for warm (El Niño) events and at or below the -0.5 anomaly for cold (La Niña) events. The normal years are in the range -0.5 to +0.5 of ONI. The data extracted from NOAA Climate Prediction Center through www.nws.noaa.gov (for 2019 data).

\section{Observation of Actual Peat Fire}

This study was carried out the observation of the vertical layer of peat temperature in 
inland peat in Ex-Mega Rice Project (EMRP) area during 2012 peak fire event under normal year (neither El Niño nor La Niña years) as mentioned in Table 1. The objective aims to investigate the average temperature of the burned peat layer in neutral years without an influence of global weather. The selection of fire point was simple random sampling and it was captured by an infrared thermal imaging camera Therma shot F30, Nippon Avionic Co., Ltd., Japan. The ability of the camera is to record the lower temperature limit of 19.9 degrees celcius and the upper limit temperature of 350 degrees celcius but the temperature will not be detected when beyond the limits. One most representative image was analyzed by unsupervised classification in QGIS software. The process of each image was identified to be a member of one of the inherent categories present in the image collection without the use of labelled training samples or rely on the computer automated classification. Number of classes are six of the temperatures range namely low, moderate, high, very high and extreme high, which the distance between each value of class is approximate 55 degrees celcius.

\section{Visibility and Particle Matter Analysis}

Daily visibility and Particulate Matter Size 10 data from 2015 to 2019 were provided by Palangka Raya Meteorology Station in Tjilik Riwut Airport $\left(2.224^{\circ} \mathrm{S}, \quad 113.946^{\circ} \mathrm{E}\right)$. Equipment for the visibility monitoring was AWI Runway Visual Range (RVR) System is based around the Model 8365-A Dual Technology Visibility Sensor. Meteorological Optical Range (MOR) is determined by measuring the optical extinction coefficient of a beam of light as it passes through a known volume of air. Any particles in the air-such as fog, rain, or snow-will affect the extinction coefficient. The extinction coefficient was then converted by the CDP to an equivalent MOR value. The sensor was polled every 10 seconds. Furthermore, measurement of PM 10 uses the Thermo Fisher Scientific (Model 5014i Beta Continuous Ambient Particulate Monitor. The Run screens display the 24hours PM concentration, ambient conditions, sample conditions, and mass sensor data. The Average PM screen displays the current average PM concentration and sets the minimum and maximum alarm limits. Acceptable alarm limits range from 0 to 10000 $\mu \mathrm{g} / \mathrm{m}^{3}$ or 0 to $10 \mathrm{mg} / \mathrm{m}^{3}$. If the average $\mathrm{PM}$ concentration goes beyond either the minimum or maximum limit, an alarm is activated and the alarm (bell) icon appears in the status bar on the Run screen. All data were averaged to represent the daily data.

To find out air quality, how clean or polluted the air quality is and how it impacts on health after inhaling the air for several hours or days, the PM 10 concentration is converted to an Air Pollution Standard Index (PSI) in the categories according from the Decree of the Environmental Impact Management Agency (Bapedal) Number KEP107 / Kabapedal / 11/1997 as shown in Table 2.

\section{RESULTS AND DISCUSSION}

\section{Annual Fire Occurrences}

Table 1 shown that the average of number of hotspot in the last twelve years is exceeds 8 000, which has the peak on September and October (about $75 \%$ of the total hotspot in Central Kalimantan). The rest occurred in the 
other ten months. Under very strong El Niño, larger than the average of the number of the peatland fires could reach 20. 000 hotspot hotspot. It is due combination of the very long such in 2015. This number is about three times ( 19months) and the very high values of ONI

Table 1. Fire occurrence and El Niño/La Niña conditions in the last fourteen years (2006 - 2019)

\begin{tabular}{|c|c|c|c|c|c|c|}
\hline \multirow{2}{*}{$\begin{array}{l}\text { Rank of } \\
\text { hotspot }\end{array}$} & \multirow{2}{*}{ Year } & \multicolumn{2}{|c|}{$\begin{array}{l}\text { Sum of num.hotspots in } \\
\text { C. Kalimantan }\end{array}$} & \multicolumn{2}{|c|}{$\mathrm{ENSO}^{2}$} & \multirow[t]{2}{*}{$\begin{array}{c}\text { Major hotspot location } \\
(>50 \% \text { of the total } \\
\text { hotspot })^{3}\end{array}$} \\
\hline & & 12 month & $\begin{array}{l}\text { Sept-Oct } \\
\text { (Peak } \\
\text { Season) }\end{array}$ & $\begin{array}{l}\text { Magnitude of } \\
\text { El Niño La } \\
\text { Niña }\end{array}$ & $\begin{array}{l}\text { Peak running 3- } \\
\text { month mean } \\
\text { ONI values }\end{array}$ & \\
\hline & & & & Very Strong El & & \\
\hline 1 & 2015 & 26,473 & 20,045 & Niño & $+2.6(\mathrm{NDJ})$ & Peatland \\
\hline 2 & 2006 & 25,450 & 19,871 & $\begin{array}{l}\text { Weak El Niño } \\
\text { Moderate El }\end{array}$ & $+0.9(\mathrm{OND})$ & Peatland \\
\hline 3 & 2009 & 13,967 & 10,510 & Niño & $+1.6(\mathrm{NDJ})$ & Peatland \\
\hline 4 & $2019^{*}$ & 11,691 & 10,065 & Weak El Niño & $+0.3(\mathrm{JJA})$ & Peatland \\
\hline 5 & 2014 & 11,337 & 8,403 & Weak El Niño & +0.7 (NDJ) & Peatland \\
\hline 6 & 2012 & 5,567 & 4,560 & $\begin{array}{c}\text { Normal } \\
\text { Moderate La }\end{array}$ & $+0.3(\mathrm{ASO})$ & Peatland \\
\hline 7 & 2011 & 5,393 & 2,384 & Niña & $-1.1(\mathrm{SON})$ & Non peatland \\
\hline 8 & 2013 & 3,395 & 3,057 & $\begin{array}{c}\text { Normal } \\
\text { Moderate La }\end{array}$ & $-0.3(\mathrm{NDJ})$ & Non peatland \\
\hline 9 & 2007 & 3,120 & 2,707 & Niña & -1.6 (NDJ) & Non peatland \\
\hline 10 & 2018 & 2,792 & 1,781 & Weak El Niño & $+0.9(\mathrm{OND})$ & Peatland \\
\hline 11 & 2008 & 1,919 & 1,390 & Normal & -0.7 (NDJ) & Non peatland \\
\hline 12 & 2016 & 640 & 370 & Weak La Niña & $-0.7(\mathrm{SON})$ & Non peatland \\
\hline 13 & 2010 & 499 & 385 & Strong La Niña & $-1.7(\mathrm{SON})$ & Non peatland \\
\hline 14 & 2017 & 349 & 250 & Weak La Niña & -0.9 (OND) & Non peatland \\
\hline Aver & & 8,042 & 6,127 & & & \\
\hline
\end{tabular}

Note:

${ }^{1}$ A confidence level above $60 \%$

${ }^{2}$ Defined by NOAA (National Oceanic and Atmospheric Administration)

${ }^{3}$ Analyzed on a map from BRG (Badan Restorasi Gambut)

${ }^{4}$ Only 10 months of hotspot data

JJA (Jun., Jul., Aug); ASO (Aug., Sept., Oct); SON (Sept., Oct., Nov.); OND (Oct., Nov., Dec); NDJ (Nov., Dec., Jan) 
(> 2.0). Indonesian peatlands are becoming a worldwide concern again in mid-2019. The total number of fire in Central Kalimantan is over 10. 000 which is almost half of the total in 2015. This year is classified as weak El Niño but it ends at the beginning of the annual dry season as in Table 1. The three of top of fire occurrences in peatland could defined by ONI (Ocean Nino index) values are greater than +0.5 and coincide with annual dry season in Central Kalimantan. The previous research indicated that the severe El Niño-induced peat fires affected by the long absence of precipitation and the minimum of ground water level in the peatland area, Central Kalimantan particularly in the Ex MRP ((Putra \& Hayasaka, 2011; Yulianti \& Hayasaka, 2013). Moreover, Limin et al. (2008) reported that the maximum underground fire was as deep as $60 \mathrm{~cm}$ below the surface in normal year. It may be hypothesized that the fire stops here due to the peat moisture at deeper layers (more than $-60 \mathrm{~cm}$ ) as the reported by Moreno et al. (2010). However, when moisture reaches less half of the total peat weight (or a tendency of irreversible drying), the smoldering would have easy to spread larger and deeper.

\section{Fire Prone and Fire Risk Areas}

This paper was defined by the side of a $0.01^{\circ}$ grid cell of the hotspot in September and October in severe fire 2015, 2014, 2009 and 2006 as shown in Figure 2. The map is also overlapped with administrative boundaries (black lines) and the distribution of peatland areas (black spots) in Central Kalimantan. The red color on the map states that the highest density is greater than or equal to 200 hotspots per year (actual condition). The most-red areas in very strong El Niño 2015 are eleven regencies where it is sorted by its distribution, namely Pulang Pisau, Kapuas, Kotawaringin Timur, Seruyan, Katingan, Kotawaringin Barat, Seruyan, Sukamara, Palangka Raya, Barito Selatan and Barito Timur. In contrast, the least red areas in the weak El Niño 2014 are far narrower in four regencies, namely Pulang Pisau, Kapuas, Kotawaringin Timur and Katingan. The interesting is fire in 2019 under weak El Niño becomes the top four fires in Central Kalimantan. It is could explain why the haze condition blanked the city of Palangka Raya around two months. In Figure 3 , the red areas are found only in peatlands, while the orange areas with greater than or equal to 150 hotspots per year and the yellow areas with greater than or equal to 100 hotspots per year can be found in nonpeatland. This further clarifies that dry peat itself is a potential fuel, where the research from Yulianti et al (2014) and Usup (2004) had shown that calorific values of peat are even higher than surface vegetation such as ferns and trees. These calorific values for peat are higher than lignite (low grade coal/brown coal) (Singh et al. 2009) and sub-bituminous coals of Central Kalimantan (Belkin et al. 2009).

For further analysis, we selected only the five regencies within the EMRP areas and its adjencent, namely Pulang Pisau, Kapuas, Palangka Raya, Barito Selatan and Katingan. Figure 3 showed the percentage of the total hotspot that has been sorted with a peat map of Badan Restorasi Gambut and compared to the total hotspot within the district administration areas analyzed by the box-and-whisker plot ( $\mathrm{n}$ $=14$ ). The most percentage of fires on peatland occurred in Pulang Pisau (red color). The minimum is $50 \%$ and the maximum is $94 \%$. The first quartile (Q1) is $65 \%$, the median is 
$81 \%$ and the third quartile (Q3) is $88 \%$. The second most in Figure 3 is in Palangka Raya, with the minimum and maximum are $8 \%$ and $85 \%$ respectively. The first quartile (Q1) is $24 \%$, the median is $51 \%$ and the third quartile (Q3) is $68 \%$. The least percentage is in
Katingan and South Barito with a maximum value of less than $30 \%$. This might illustrate that the majority of forest and land fires were not occur in peatland areas for the both regencies.
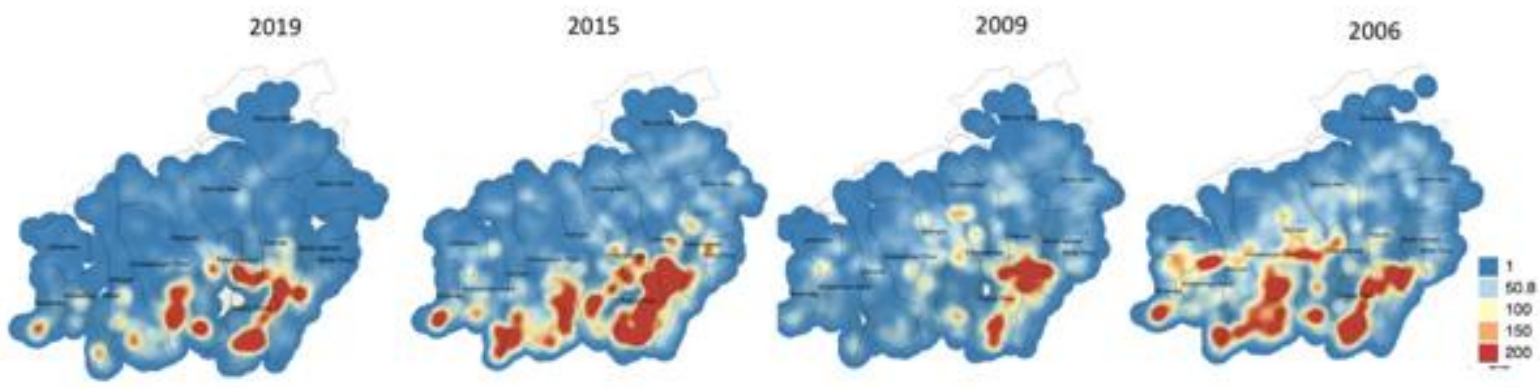

Figure 2. Maps of the epicenter of hotspot of the kernel density estimates September and October's peak in 2006, 2009, 2015, and 2019.

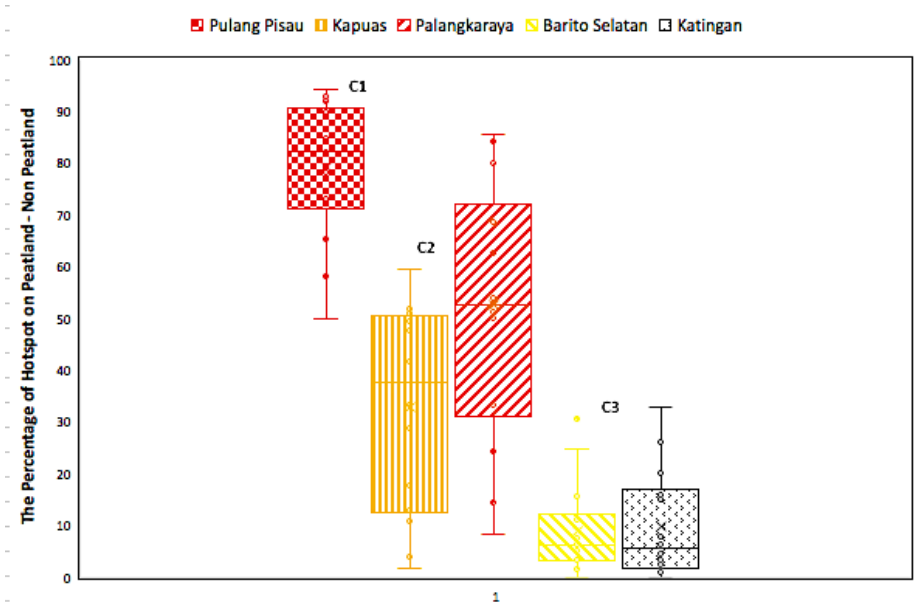

Figure 3. The cluster of hotspot percentage in peatland.

As explained in the results above in Figure 3 , the two highest fires on peatland were recorded in Pulang Pisau and Palangka Raya. Figure 5 showed that fire risk maps (potential condition) in Pulang Pisau Regency with three level "5" very high, "4" high and " 3 " moderate in left side. Figure 6 is produced the same as picture 5 for the Palangka Raya City. This map is extracted from the data of the official Fire Risk System website which is provided at open access on www.kebakaranhutan.or.id. Data based on MODIS hotspots are connected 
to the other environmental variables such as regional planning maps, land system information, land cover, peat depth, hotspots to rivers, roads and city centers. Significant changes in land use and land cover in recent decades (right side), especially in peatlands, have been identified as a determining factor.
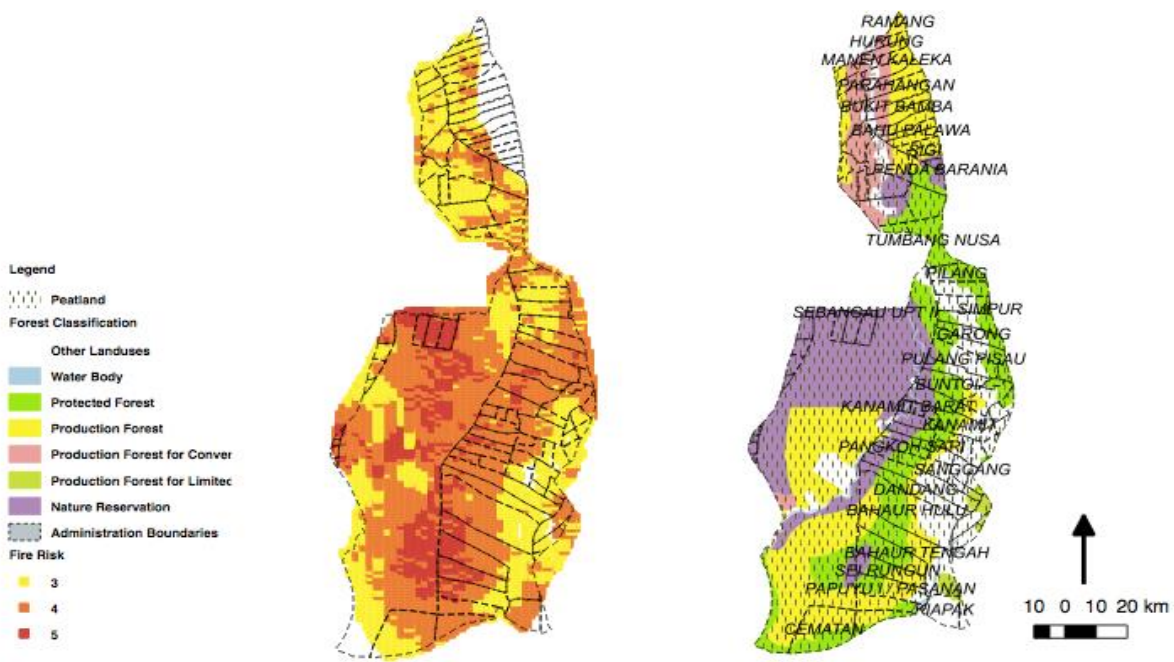

Figure 4. Maps of fire risk and the land cover (from Figure 1) in Pulang Pisau
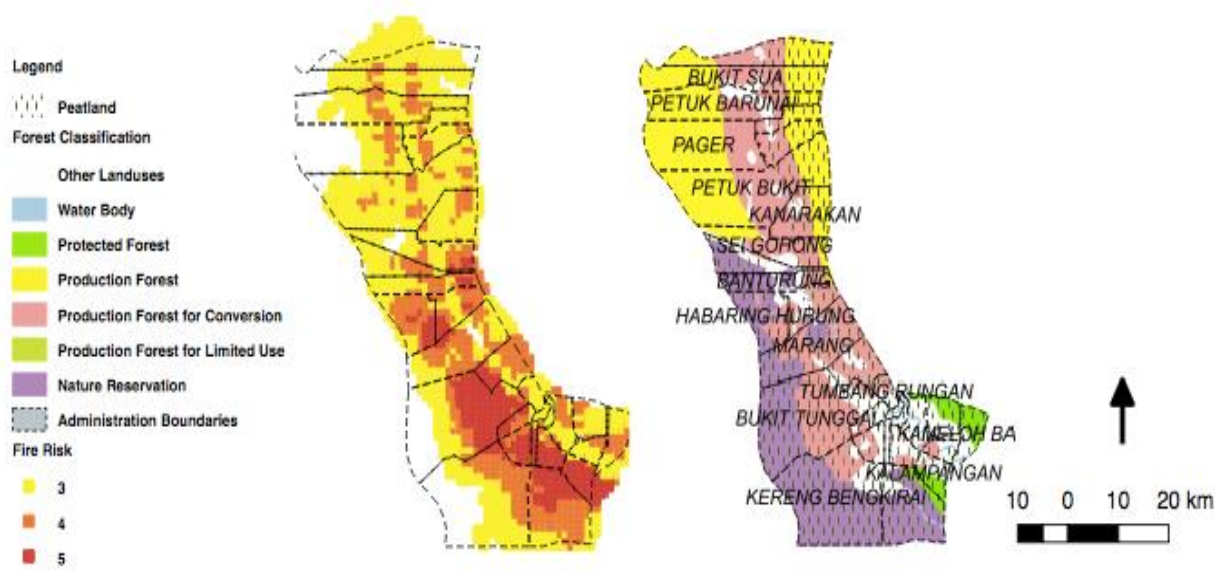

Figure 5. Maps of fire risk and the land cover (from Figure 1) in Palangka Raya

The area of very high and high vunerability This is related to the thickness of the peat in in Pulang Pisau are located in protected forest both land cover. Research from Damanik and nature preservation as show in Figure 4. (2015), and Adji (2017) shows that the 
presence of peat domes from the south to the west of the district of Pulang Pisau. Yulianti (2018) shows a picture that the area has many canals and is categorized as the priority area for peat restoration. In Figure 6, the southern part of Palangka Raya is the very high and high vunerability in the production forest for conversion, the nature reservation and the other land uses. These areas also have thick peat as mentioned in Setiadi et al (2016). There are also many urban drainages such as in village of Bukit Tunggal and canals associated with agriculture in the village of Kalampangan. When the domes or thick peat layer become very dry due to the canals, it is very potential as a fuel for further fires.

\section{Peat Fire Characteristics}

A typical surface fire situation in abandoned peatland with three combustion types, namely, flaming, smoldering, and glowing. The active fire with flaming has high flame temperatures, around more than $800^{\circ} \mathrm{C}$ (Saharjo, 2006). Under high temperatures, not only dead vegetative matter such as trees, bushes, grass, and ferns but also fresh, growing vegetable matter in this vegetation burn with relatively high fire spreading rates. Smoldering and glowing fires are flameless combustion and show low spreading rates due to lower temperatures.

Above the forest and land floor, fire comes with flames or of this type of fire, called surface fires. In abandoned peatland, surface fires also could reach dangerous levels mainly due to ferns. Page et al. (2009) stated that peatland dominated with ferns over more than $50 \%$ of the total area could be a high fire risk, as ferns are a favorable fuel with its high calorific value and low ignition temperature; its values are the same as peat (Yulianti, 2018). This means that ferns are fire prone vegetation, particularly under dry conditions.

The fire spreading behavior could be simply explained by heat flows near the ground surface. At the top of the peat layer or ground surface, heat from peat fires warms air near the surface and the heated air moves upward. With this movement, cool surrounding air would move into the surface area and cool the surface. However, with the burning underground peat, the cooling flow of incoming air disrupted by the heat rising from the fire zone and so there is no flow of cooling air. Further, this kind of peat fire tends to move toward underground layers and it was observed that these fires leave deep holes with depths of more than $30 \mathrm{~cm}$ at the peat fire site. As a result, the spreading rate of peat fires becomes relatively slower due to the smoldering type of peat combustion underground with low temperature combustion (around 500 or $600^{\circ} \mathrm{C}$ ) (Rein et al. 2008). This unique fire behavior answers some of the question why smoldering fires occur over long durations, and why peat fires are difficult to extinguish. 


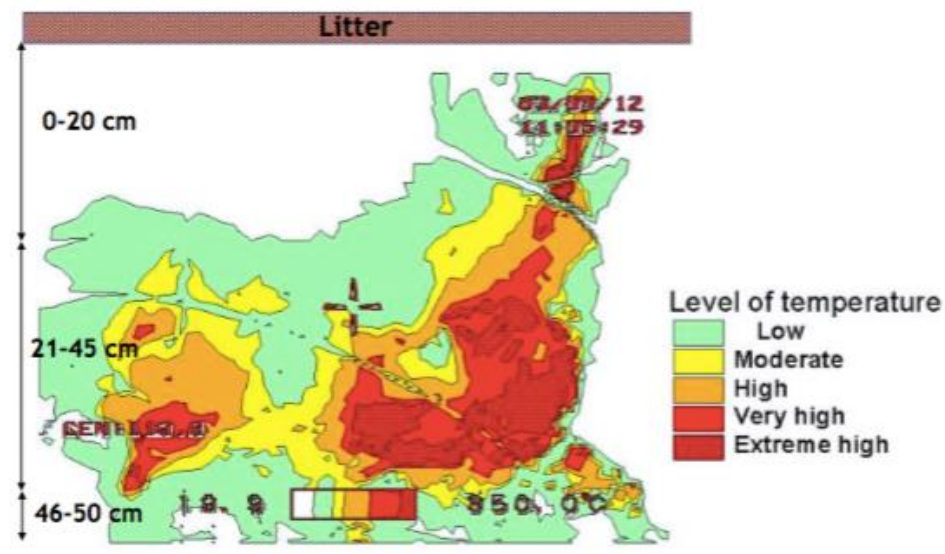

Figure 6. Temperature profile of peat fire

Observation of temperature changes in the peat layer had done during a fire period in 2012 fire event as mentioned in methodology. In this study, the IR-image from peat fire 0-50 $\mathrm{cm}$ was classified using several categories in order to show the variation of peat layer temperature as shown in Fig. 6. From the extreme high to the high temperature occurred mostly in depth of exceed $20 \mathrm{~cm}$ below ground. In the other hand, low temperature occurred in surface ground. It is one of the reasons why peat fire very difficult to recognized by the naked eye. In some areas, we were hard to found smoke and heat radiation on surface as a sign of peat fire, particularly after the rain or water injection by fire fighter.

\section{Air Pollution related Peat Fire}

In Palangka Raya, dangerous air pollution with PM10 concentrations of more than 500 ug $\mathrm{m}^{-3}$ occured for 2 (two) months namely September and October of 2015 (rank 1 of 14years of hotspot) and 2017 (rank 14 of 14years of hotspot). Based on data obtained from measurements at the Tjilik Riwut Station in
Palangka Raya, the smog that covered Palangka Raya was getting thicker by the end of October. As a result, visibility is increasingly limited, which was lower than $1000 \mathrm{~m}$ during the peak air pollution season in 2015 (Figure 7). As a comparison, the images of aerosol thickness from NASA Terra of MODIS satellites during September 2015 are show very concentrated (dark brown) above Palangka Raya (https://neo.sci.gsfc.nasa.gov/).

From the results of the analysis, we can see that the PSI was above $600 \mu \mathrm{g} \mathrm{m}^{-3}$ for two months in 2015 (Figure 7a and result of Hayasaka \& Sepriando, 2018). As a result of high particle concentrations, Palangka Raya is covered by dark fog and there are also indications that oxygen concentrations decrease when the haze peaks impact on human, but this needs to be evaluated with continued health research. This thick and toxic smoke condition is very detrimental not only health and social community but also the environment and influencing future climate change conditions (Limin et al. 2007; Stockwell et al. 2016; Kim et al. 2015; Koplitz et al. 2018; Uda et al. 2019). On contrary, the 
indexes in 2017 are show that good air quality below than $50 \mathrm{\mu g} \mathrm{m}^{-3}$ for whole year (Figure 7b). This value seems to be tolerable by human, animal and sensitive plants because the peat fires in this year are far below the average in the past fourteen years. Even it is lower than the year with a strong La Niña in 2010 as showed by Table 1 . The PSIs in the highest fire in 2015 is about 50 times greater than the lowest fire in 2017. In other words, the condition of air pollution in 2015 probably have a multiplied impact on living things, especially humans and animals. It was stated by our social survey study in villages in Pulang Pisau, Palangka Raya and Katingan (Yulianti et al. 2020).

Table 2. The PSI categories of PM 10

\begin{tabular}{|c|c|c|c|}
\hline PSI & Category & $\begin{array}{c}24 \text { hours of PM10 } \\
\mu \mathrm{g} \mathrm{m}^{-3}\end{array}$ & Health Impacts \\
\hline 10 & Good & $\leq 50$ & does not affect human or animal health. \\
\hline 100 & Moderate & $\leq 150$ & $\begin{array}{l}\text { has no effect on human or animal health } \\
\text { but affects sensitive plants }\end{array}$ \\
\hline 200 & Unhealthy & $\leq 350$ & $\begin{array}{l}\text { is detrimental to humans or groups of } \\
\text { animals that are sensitive or can cause } \\
\text { damage to plants or aesthetic value. }\end{array}$ \\
\hline 300 & Very Unhealthy & $\leq 420$ & $\begin{array}{l}\text { air quality which can be detrimental to } \\
\text { health in a number of exposed population } \\
\text { segments. }\end{array}$ \\
\hline 400 & \multirow[t]{2}{*}{ Hazardous } & $\leq 500$ & \multirow{2}{*}{$\begin{array}{l}\text { dangerous air quality which in general can } \\
\text { seriously harm health in the population (eg } \\
\text { eye irritation, coughing, phlegm and sore } \\
\text { throat). }\end{array}$} \\
\hline 500 & & $\leq 600$ & \\
\hline
\end{tabular}

Journal of Wetlands Environmental Management

Vol 8, No 2 (2020) 100 - 116 

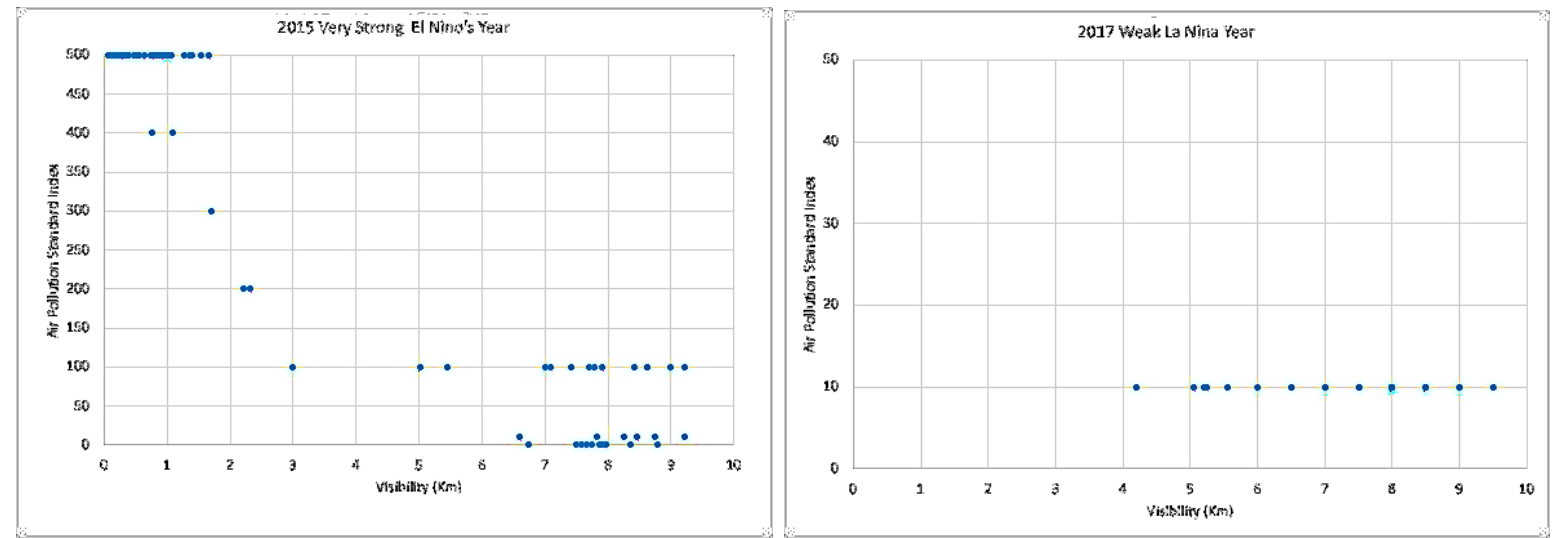

Figure 7. The PSI and visibility from (a) August to November 2015 (Highest Fire Occurrences) and (b) 2017 (Lowest Fire Occurrences)

\section{CONCLUSSION}

A comparison of hotspot, ONI, visibility and PSI dataset from 2006 to 2019 in Central Kalimantan concluded that the 2015 is the most El Niño-induced fires occurrences with hazardous haze condition. On the contrary, the 2017 is the least La Niña-induced fire occurrences with good haze condition. Thousand hotspots were recorded on the peatlands in Central Kalimantan only during El Niño such as 2019, 2015, 2014, 2009 and 2006, except 2012 for the normal year. The exception of 2012 fire occurrences been the reason for this study to observe the peat fires. A temperature profile investigation shows that extreme high temperatures in the peat layer hole but lowest temperatures or flameless on the surface. Commonly, those type of fires are release small energy, persistent spread, longlast but often neglectable during the fire extinguishing activities. The peat fire accumulation on a large scale and in simultaneously could emit brown smoke and be the source of thick haze for the surrounding areas.

\section{ACKNOWLEGEMENT}

Great thanks to Mr. I Wayan Mustika, Mr. Anton Budiyono, Mrs. Catur Winarti, and Mrs. Aslaili Mardiyah of Palangka Raya Meteorology Station in Tjilik Riwut Airport for the weather, visibility and PM 10 data. The main study is results of research collaboration University of Palangka Raya and CIFOR under a grant of Ministry of Agriculture, Forestry and Fishery, Japan (MAFF). A part of spatial data analysis was supported by the Ministry of Science, Technology and Higher Education, Republic of Indonesia during "SAME 2018" program in Center of South East Asia (CSEAS), Kyoto University, Japan.

\section{REFERENCES}

Adji FF, Damanik Z, Yulian N, Teguh R,TarunaY, Saman TN, Barbara B. 2017. Explortion on of Peat Swamp Ecosystem in KHG Kahayan - Sebangau as a Restora on Reference Area. Report. UPT. LLG CIMTROP, University of Palangka Raya. [in Bahasa] 
Barbara, B., Yulianti, N., Firdara, EK. 2015. Knowledge, Attitude, and Practice (KAP) Impact on Land and Forest Fire in the province of Central Kalimantan. J-SEA (Journal Socio Economics Agricultural) 10:1-13 [in Bahasa]

Belkin, H.E., Tewalt, S.J.,Hower, J.C., Stucker, J.D., O'Keefe, J.M.K. 2009. Geochemistry and Petrology of Selected Coal Samples from Sumatra, Kalimantan, Sulawesi, and Papua, Indonesia. International Journal of Coal Geology 77: 260-268. Intervention and the Role of Forest Fires in Human Ecology. The Science of the Total Environment 292: 141-165

Conedera, M., Tinner, W. 2000. The Interaction Between Forest Fire and Human Activity in Southern Switzerland. In: Innes, J.L., Beniston, M., Verstraete, M. M (eds). 2000. Biomass Burning and Its Interrelationship with the Climate System. Kluwer Academic Publishers. Netherlands.

Damanik, Z. 2015. Kajian Kimia Air Gambut pada Lahan Gambut dengan Substrat Umur Bahan Sulfidik. [dissertation]. Yogyakarta: Universitas Gadjah Mada.

Harvey, B.J. 2016. Human-caused Climate Change is Now A Key Driver of Forest Fire Activity in the Western United States. PNAS. 113: 11649-11650

Hayasaka H., Noguchi I., Putra E.I., Yulianti N. and Vadrevu K., 2014. Peat-fire-related Air Pollution in Central Kalimantan, Indonesia. Environmental Pollution 195: 257-266.

Hayasaka, H and Sepriando, A. 2018. Severe Air Pollution Due to Peat Fires During 2015 Super El Niño in Central Kalimantan, Indonesia. In: Vadrevu K., Ohara T., Justice
Caldararo, N. 2002. Human Ecological

C. (eds) Land-Atmospheric Research Applications in South and Southeast Asia. Springer Remote Sensing/Photogrammetry. Springer, Cham.

Heil, A., B. Langmann and E. Aldrian. 2006. Indonesian Peat and Vegetation Fire Emissions: Study on Factors Influencing Large-Scale Smoke Haze Pollution Using A Regional Atmospheric Chemistry Model. Mitigation and Adaptation Strategies for Global Change 12: 113-133.

Hooijer, A., M. Silvius, H. Wosten, S. Page. 2006 "Peat- $\mathrm{CO}_{2}$ : Assessment of $\mathrm{CO}_{2}$ Emission from Drained Peat- lands in SE Asia," Delft Hydraulics Report Q3943.

Huang, B., Thorne, P. W., Banzon, V. F., Boyer, T., Chepurin, G., Lawrimore, J. H., Menne M. J., Smith, T. M., Vose R. S., and Zhang, H. M. 2017. Extended Reconstructed Sea Surface Temperature, Version 5 (ERSSTv5): Upgrades, Validations, and Intercomparisons, J. Climate $\quad 30: \quad 8179-8205$, https://doi.org/10.1175/JCLID-16-0836.1.

Huijnen, V., Wooster, M.J., Kaiser, J.W., Gaveau, D.L.A., Flemming, J., Parrington, M., Inness, A., Murdiyarso, D., Main, B. \& van Weel, M. 2016. Fire Carbon Emissions Over Maritime Southeast Asia in 2015 Largest Since 1997. Scientific Reports 6:19.

Kim, P. S., Jacob, DJ, Mickley, LJ, Koplitz, S.N, Marlier, ME,. DeFries, RS, Myers, SS., Chew, B.N, Mao, YH. 2015. Sensitivity of Population Smoke Exposure to Fire Locations in Equatorial Asia. Atmospheric Environment 102: 11-17. http://dx.doi.org/10.1016/j.atmosenv.2014.0 9.045

Koplitz, S. N., Mickley, L. J., Jacob, D. J., Marlier, M. E., DeFries, R. S., Gaveau, 
D. L. A., Locatelli, B., Reid, J. S., Xian, P., \& Myers, S. S. (2018). Role of the MaddenJulian Oscillation in the Transport of Smoke from Sumatra to the Malay Peninsula during Severe Non-El Niño Haze Events. Journal of Geophysical Research: Atmospheres 123:62826294. http://doi.org/10.1029/2018JD02853 $\underline{3}$

Limin, S, H, S. Alim, Y. Rogath, Yarden, Fransiscus A.H., Kusin, K., Purnomo, A., Patih R., Restu,A., Ermiasi, Y., Erisa I.S., and Haga. 2008. The TSA Concept Relevant to Supporting REDD Program Implementation. In: Proceeding Peatland Development: Wise Use and Impact Management. The International Symposium and Workshop on Tropical Peatland, Kuching, Malaysia.

Limin, S, H., H. Takahashi, A,Usup, H,Hayasaka, M, Kamiya and N, Murao. 2007. Impacts of Haze in 2002 on Social Raya. Tropics 16: 275-282.

MacDonald, K. 2017. The Use of Fire and Human Distribution. TEMPERATURE 4:153-165

https://doi.org/10.1080/23328940.2017.128 4637

Moreno, L., Maria-Emilia Jiménez, Héctor Aguilera, Patricia Jiménez and Almudena de la Losa. 2010. The 2009 Smouldering Peat Fire in Las Tablas de Daimiel National Park (Spain). Fire Technology 2: 1-10.

Noor Muhammad, 2001. Pertanian Lahan Gambut, Potensi dan Kendala, Gadjahmada University Press. Yogyakarta.

Page, S. E., Agata Hostilo, Andreas Langner, Kevin Tansey, Florian Siegert, Suwido Limin, and Jack Rieley. Tropical peatland fires in Southeast Asia. In: Mark A. Activity and Human Health in Palangka

Cochrane. 2009. Tropical Fire Ecology Climate Change, Land use and Ecosystem Dynamics. Praxis Publishing, Chichester, UK, 263-287 pp

Page, S.E., F. Siegert, J. O. Rieley, H.D. V. Boehm, A. Jaya, S. Limin. 2002. The Amount of Carbon Release from Peat and Forest Fires in Indonesia During 1997. Nature 420, 61-65.

Putra E. I., H. Hayasaka. 2011. The Effect of the Precipitation Pattern of the Dry Season on Peat Fire Occurrence in the Mega Rice Project Area, Central Kalimantan, Indonesia. Tropics 19: 145-156.

Putra, E. I., H. Hayasaka, H. Takahashi, A. Usup. 2008. Recent Peat Fire Activity in the Mega Rice Project Area, Central Kalimantan, Indonesia. Journal of Disaster Research 3: 334-341.

Rein, G., Natalie Cleaver, Clare Ashton, Paolo Pironi, and José L. Torero. 2008. The severity of Smouldering Peat Fires and Damage to the Forest Soil. Catena 74: 304309.

Saharjo, B. H. 2006. Fire behavior in Pelalawan Peatland, Riau Province. Biodiversitas 7: 90-93.

Scott, A. C., Bowman, D. J. M. S., Bond, W. J., Pyne, S. J., Alexander, M. 2014. Fire on Earth: An introduction. Chichester, UK: Wiley-Blackwell.

Setiadi, IC, Yulianti, N, Adji FF. 2016. Evaluasi Sifat Kimia dan Fisikgambut dari Beberapa Lokasi di Blok C Eks-PLG Kalimantan. AGRI PEAT 19:1-14.

Singh, R.M., Kim,H., Kamide, M., Sharma, t. 2009. Biobriquettes An Alternative Fuel for Sustainable Development. Nepal Journal of Science and Technology 10: 121-127.

Stockwell, C. E., Jayarathne, T., Cochrane, M. A., Ryan, K. C., Putra, E. I., Saharjo, B. H., 
Nurhayati, A. D., Albar, I., Blake, D. R., Simpson, I. J., Stone, E. A., and Yokelson, R. J.. 2016. Field Measurements of Trace Gases and Aerosols Emitted by Peat Fires in Central Kalimantan, Indonesia, During the 2015 El Ninõ, Atmos. Chem. Phys. 16: 11711-11732, https://doi.org/10.5194/acp16-11711- 201.

Struzik, E. 2017. Firestorm: How Wildfire Will Shape Our Future. Island Press.

Syphard AD, Sheehan T, Rustigian- Romsos H, Ferschweiler K. 2018. Mapping Future Fire Probability under Climate Change: Does Vegetation Matter? PLoS ONE 13 (8): $\mathrm{e} 0201680$. https://doi.org/10.1371/journal.pone.02016 80

Taylor, D. 2010. Biomass Burning, Humans and Climate Change in Southeast Asia Biodivers Conserv. 19:1025-1042. DOI 10.1007/s10531-009-9756-6

Uda, S.K., Hein, L., Atmoko, D. 2019. Assessing the Health Impacts of Peatland Fires: A Case Study for Central Kalimantan, Indonesia. Environmental Science and Pollution Research 26:_3131531327. https://doi.org/10.1007/s11356-01906264-x

Usup, A. 2004. Peat Fire Characteristics in Central Kalimantan. [dissertation]. Sapporo: Hokkaido University.
Van Mead, N. 2017. Pant by Numbers: the Cities with the Most Dangerous Air, Listed. The Guardian, February 13, 2017. https://www.theguardian.com/cities/datablo $\mathrm{g} / 2017 / \mathrm{feb} / 13 /$ most-polluted-cities-worldlisted-region (accessed 10 March 2017).

Wetlands. 2004. Maps of Area of Peatlands Distribution and Carbon Content in Kalimantan. Wetlands InternationalIndonesia Programme, Bogor.

Yulianti, N. 2018. Introduction of Fire Disaster and Transboundary Haze (Case Studi Ex - Mega Rice Project. IPB Press. Bogor [in Bahasa]

Yulianti, N., H. Hayasaka, A. Usup. 2014. Biomass Fuels Properties from Burned Peatland. Jurnal AGRI PEAT 15: 10-16.

Yulianti, N., Hayasaka, H. 2013. Recent Active Fire under El Niño Conditions in Kalimantan, Indonesia. American Journal of Plants Science 4: 685-696

Yulianti, N., Hayasaka, H., Usup, A. 2012. Recent Forest and Peat Fire Trends in Indonesia, the Latest Decade by MODIS hotspot data. Global Environmental Research 16: 105-116.

Yulianti, N., Kusin, K., Murni, E., Dedy, Barbara, B., Naito, D., Jagau, Y., Kulu, I.P., Susetyo, K.E. 2020. Analisa Penyebab Dan Dampak Kebakaran Hutan - Lahan Gambut Di Kalimantan Tengah. Ecotrophic Journal ( In-review). 